\title{
Sequence Specific Retention Factor
}

National Cancer Institute

\section{Source}

National Cancer Institute. Sequence Specific Retention Factor. NCI Thesaurus. Code C82337.

Predicts the retention time of tryptic peptides during RP-HPLC fractionation based on the hydrophobicity measure algorithm of Krokhin et al. (Mol Cell Proteomics. 2004 Sep;3(9):908-19. Epub 2004 Jul 6) 